http://jmscr.igmpublication.org/home/ ISSN (e)-2347-176x ISSN (p) 2455-0450 crossref DOI: https://dx.doi.org/10.18535/jmscr/v7i7.174

Journal Of Medical Science And Clinical Research

\title{
Evaluation of the Effect of Various Intra Operative Surgical Complications on Central Corneal Endothelial Cell Density and Central Corneal Thickness- A Prospective Study
}

\author{
Authors \\ Dr Sachin Tammannavar ${ }^{1 *}$, Dr Ramesh ${ }^{2}$, Janice Reema Lewis ${ }^{3}$, Harshitha ${ }^{4}$, \\ Hemanth Raju M R $\mathbf{R}^{5}$ \\ ${ }^{1}$ Assistant Professor and I/C HOD Department of Ophthalmology, Karwar Institute of Medical Sciences, \\ Karwar-581301 (India) \\ ${ }^{2}$ Senior Resident, Department of Ophthalmology, Karwar Institute of Medical Sciences, \\ Karwar-581301 (India) \\ 3,4,5 Pre Final Year Karwar Institute of Medical Sciences, Karwar-581301 (India) \\ *Corresponding Author \\ Dr Sachin Tammannavar \\ Karwar Institute of Medical Sciences, Karwar- 581301(India)
}

\begin{abstract}
Purpose: To evaluate the effect of various intra operative surgical complications on Central Corneal Endothelial Cell Density and Central Corneal Thickness

Methods: A prospective study comprising of 222 patients who underwent small incision cataract surgery, which were divided into three groups.

G1 -Irrigating vectis technique-73 patients

G2-Sandwich technique-75 patients

G3 -Visco expression technique-74 patients.

All patients underwent complete ophthalmic examination and biometry followed by measurement of central corneal thickness, specular microscopy (endothelial images) was performed at baseline (preoperative) and postoperatively at 1week, 2 weeks, 1 month and 3 months.

Results: In our study, out of 222 patients, 180 patients had uneventful and 42 patients had complicated surgeries. In that 42 complicated surgeries,

-11 patients had instrumental trauma (26.2\%) which caused $25.2 \%$ endothelial cell loss ( $p$ value 0.001 ) and $5 \%$ increase in CCT.

-14 patients had Iris prolapse (33.3\%) which caused $19.1 \%$ cell loss ( $p$ value 0.001) and 0.9\% increase in CCT

-7 patients had IOL Contact (16.7\%) which caused $13.1 \%$ cell loss (p value 0.003) and 1.9\% increase in CCT -9 patients had vitreous loss (21.4\%) which caused $11.5 \%$ cell loss ( $p$ value 0.039 ) and $0.9 \%$ increase in CCT and 1 patient had Iris posterior capsular rent (2.4\%) which caused $11.3 \%$ cell loss and $0.9 \%$ increase in CCT at 3 months post operatively.

In all 42 complicated surgeries, average $10.6 \%$ cell loss and $5.8 \%$ increase in CCT was found. In all 180 uneventful surgeries, average $9.5 \%$ cell loss and $3.48 \%$ increase in CCT was found.

Conclusion: Percentage of endothelial cell loss and increase in central corneal thickness was more in complicated surgeries, than uneventful surgeries.
\end{abstract}




\section{Introduction}

Cataract is opacity of natural, crystalline lens of the eye and remains the most frequent cause of blindness in the world today ${ }^{1}$. World Health Organisation estimates that $50 \%$ of persons currently blind worldwide are blind from cataract. Because of increasing population and the increasing life expectancy, the number of older people will double from 606 million in 2000 to 1.2 billion in $2025^{2}$.

In the last couples of decades, the choice of cataract surgery has shifted to mainly suture less small incision cataract surgery (SICS) or Phacoemulsification (PE). Phacoemulsification is preferred choice in the western developed countries or in urban settings. SICS is significantly faster, less expensive, and less technology dependent than phacoemulsification ${ }^{3}$. The visual acuity and the complication rates are similar to phacoemulsification (Ruit et al 2007) ${ }^{4}$. SICS may be the appropriate surgical procedure treatment of advanced cataract in the developing world. But often concern has been raised regarding the changes in the corneal thickness and endothelial cell loss following SICS $^{5}$.

Corneal endothelium is metabolically active and responsible for keeping the corneal stroma in its usual dehydrated state of $70 \%$ water $^{6}$. The normal endothelial cell density is approximately 2600 to 2800 cells $/ \mathrm{mm}^{2}$. $^{2}$

Endothelial injury may occur during cataract surgery due to number of factors such as corneal distortion, movement of nuclear fragments, release of free radicals, turbulence of irrigating solution and instrument contact $^{8}$. Moderate damage of the corneal endothelium during surgery may lead to a transient increase in corneal thickness, all these things leads to swelling of cornea ${ }^{9}$. Since the cornea swells in the direction of thickness, therefore precise measurement corneal thickness serves as a parameter for assessing overall endothelial function ${ }^{10}$.

Some degree of endothelial cell loss invariably occurs in all types of cataract surgery but the amount of endothelial cell loss varies with the surgical technique and the associated complications ${ }^{2}$. Therefore in this present study we made an attempt to access the relation between Central Corneal Endothelial Cell Density and Central Corneal Thickness after Small Incision Cataract Surgery and the effects of intraoperative complications.

\section{Materials and Methods}

This study was conducted in Department Of Ophthalmology in Karwar Institute of Medical Sciences and Hospital between 2018 November2019 October. The study was approved by the Institutional Review Board (Scientific) and written informed consent was obtained from all subjects prior to participation. Some of the consents were in local language to ensure validity. Patients were free to withdraw from the study at anytime and were assured that the study would not compromise the quality of their eye care.

This prospective study comprised of 222 patients who underwent small incision cataract surgery. Patients were selected by simple random sampling and were followed up for a 3 months.

\section{Source of data}

1) Patients attending out patients department.

2) Patients referred from other department.

All patients underwent complete ophthalmic examination and biometry followed by measurement of central corneal thickness, specular microscopy (endothelial images) was performed at baseline (preoperative) and postoperatively at 1week, 2 weeks, 1 month and 3 months.

Study Design: Prospective Clinical Study.

Sample Population: Total 222patients which were divided into 3 groups

G1 -Irrigating vectis technique-73 patients

G2-Sandwich technique-75 patients

G3 -Visco expression technique-74 patients.

\section{Inclusion Criteria}

1. Patients with senile cataract with age group of 50 years and above were included in the study.

\section{Exclusion Criteria}

-Coexisting ocular disease;

1) Increased intraocular pressure 
2) Uveitis

3) Pseudo exfoliation; and poor pupillary dilatation.

4) Corneal dystrophy, corneal scarring

-An endothelial cell count (ECC) less than 1500 cells $/ \mathrm{mm}^{2}$

-History of any intraocular surgery or ocular trauma.

\section{Observations}

The present prospective study was conducted in Department Of Ophthalmology in Karwar Institute of Medical Sciences and Hospital between 2018 November-2019 October. This study comprised of 222 patients who underwent small incision cataract surgery, which were divided into 3 groups and were followed up for a 3 months.

G1 -Irrigating vectis technique-73 patients

G2-Sandwich technique-75 patients

G3 -Visco expression technique-74 patients.

In this, we studied 42 complicated and 180 uneventful surgeries.

Table 1: Age and Sex wise distribution of patients

\begin{tabular}{|l|c|c|c|c|c|c|}
\hline $\begin{array}{l}\text { Age } \\
\text { (years) }\end{array}$ & Females & $\begin{array}{c}\% \\
\text { Females }\end{array}$ & Males & $\begin{array}{c}\% \\
\text { Males }\end{array}$ & Total & $\begin{array}{c}\% \\
\text { Total }\end{array}$ \\
\hline $\mathbf{5 0 - 5 9}$ & 47 & 42.3 & 34 & 30.6 & 81 & 36.5 \\
\hline $\mathbf{6 0 - 6 9}$ & 40 & 36.0 & 54 & 48.6 & 94 & 42.3 \\
\hline $\mathbf{7 0 - 7 9}$ & 19 & 17.1 & 21 & 18.9 & 40 & 18.0 \\
\hline $\mathbf{> 8 0}$ & 5 & 4.5 & 2 & 1.8 & 7 & 3.2 \\
\hline Total & 111 & 100.0 & 111 & 100.0 & 222 & 100.0 \\
\hline
\end{tabular}

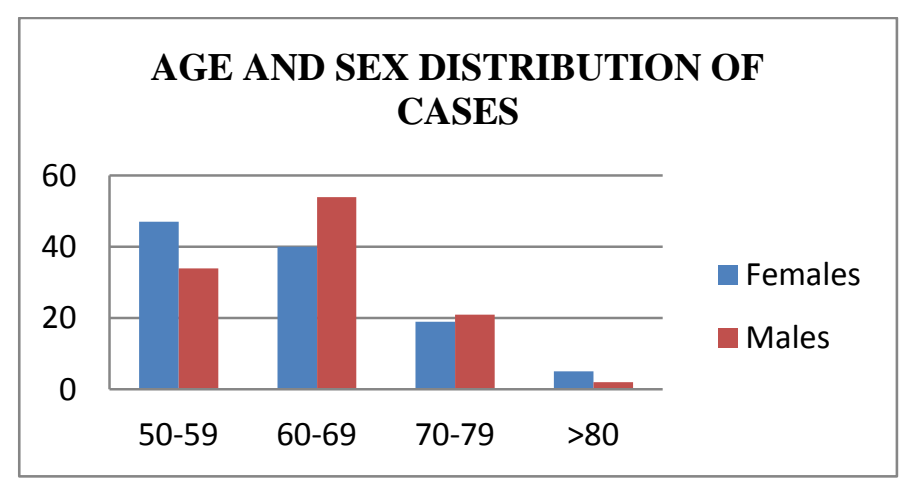

The above table and graph shows the age and sex wise distribution of 222 patients. The study was conducted on 222 patients.

The gender distribution of the study was uniform with 111 males and 111 females.

Table-2: Distribution of patients according to surgical complications

\begin{tabular}{|l|c|c|}
\hline Complications & Frequency & Percent \\
\hline Instrumental Trauma & 11 & 26.2 \\
\hline Iris Prolapse & 14 & 33.3 \\
\hline Vitreous Loss & 9 & 21.4 \\
\hline IOL Contact & 7 & 16.7 \\
\hline PCR & 1 & 2.4 \\
\hline Total & 42 & 100.0 \\
\hline
\end{tabular}

\section{DISTRIBUTION OF PATIENTS ACCORDING TO SURGICAL COMPLICATIONS}

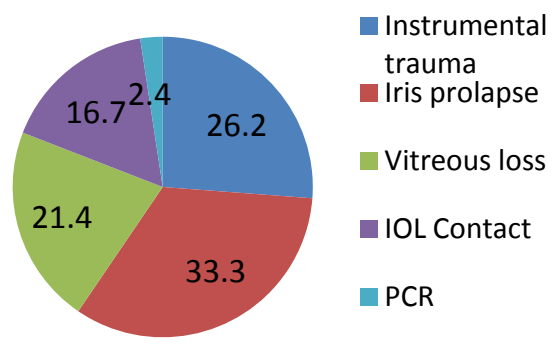

Instrumental trauma occurred in $11(26.2 \%)$ patients out of total patients with surgical complications. Iris prolapse occurred in 14 (33.3\%) patients out of total patients with surgical complications. Vitreous loss occurred in $9(21.4 \%)$ patients out of total patients with surgical complications. IOL contact occurred in $7(16.7 \%)$ patients out of total patients with surgical complications.PCR occurred in 1(2.4\%) patient out of total patients with surgical complications.

Table-3: Pre-operative and Post-operative Endothelial cell density (cells $/ \mathrm{mm}^{2}$ ) in Uneventful SICS patients.

\begin{tabular}{|c|c|c|c|c|c|c|c|c|}
\hline Complication & $\begin{array}{c}\text { No of } \\
\text { pts }\end{array}$ & $\begin{array}{c}\text { Pre-op } \\
\text { ECD } \\
(\text { mean } \pm \text { SD })\end{array}$ & $\begin{array}{c}1^{\text {st }} \text { wk ECD } \\
(\text { mean } \pm \text { SD })\end{array}$ & $\begin{array}{c}2^{\text {nd }} \text { wk } \\
\text { ECD } \\
(\text { mean } \pm \text { SD })\end{array}$ & $\begin{array}{l}4^{\text {th }} \text { wk ECD } \\
(\text { mean } \pm \text { SD })\end{array}$ & $\begin{array}{c}\text { ECD at } 3 \\
\text { months } \\
(\text { mean } \pm \text { SD })\end{array}$ & $\begin{array}{c}\text { \% Of Cell loss at } \\
3 \text { months post } \\
\text { op }\end{array}$ & $\begin{array}{c} \\
\text { value } \\
(\mathbf{Z} \text { test }) \\
\end{array}$ \\
\hline Uneventful & 180 & $2745 \pm 279$ & $2362 \pm 351$ & $2296 \pm 392$ & $2330 \pm 404$ & $2485 \pm 369$ & 9.5 & $<0.001$ \\
\hline
\end{tabular}




\section{JMSCR Vol||07||Issue ||07||Page 985-994||July}

The above table and graph shows pre-operative and post-operative endothelial cell density in uneventful SICS patients.

In the 180 patients who had uneventful SICS and the mean ECD at 3 months was $2485 \pm 369$ indicating $9.5 \%$ of cell loss at 3 months postoperatively. (P value $<0.001$ )

Table-4: Pre-operative and Post-operative central corneal thickness (microns) in Uneventful SICS patients

\begin{tabular}{|c|c|c|c|c|c|c|c|c|}
\hline Complications & $\begin{array}{l}\text { No } \\
\text { of } \\
\text { pts }\end{array}$ & $\begin{array}{l}\text { Pre-op } \\
\text { CCT } \\
(\text { mean } \pm S D)\end{array}$ & $\begin{array}{l}1^{\text {st }} \text { wk CCT } \\
(\text { mean } \pm \text { SD })\end{array}$ & $\begin{array}{l}2^{\text {nd }} \text { wk } \\
\text { CCT } \\
(\text { mean } \pm S D)\end{array}$ & $\begin{array}{l}4^{\text {th }} \text { wk CCT } \\
(\text { mean } \pm \text { SD })\end{array}$ & $\begin{array}{l}\text { 3month } \\
\text { CCT } \\
(\text { mean } \pm S D)\end{array}$ & $\begin{array}{l}\% \text { Of change in } \\
\text { CCT at } 3 \text { month }\end{array}$ & $\begin{array}{l}P \\
\text { value }\end{array}$ \\
\hline Uneventful & 180 & $526 \pm 37$ & $564 \pm 42$ & $554 \pm 37$ & $546 \pm 38$ & $545 \pm 38$ & 3.48 & 0.13 \\
\hline
\end{tabular}

\begin{tabular}{|c|c|}
\hline \multicolumn{2}{|c|}{$\begin{array}{l}\text { PRE-OPERATIVE AND POST- } \\
\text { OPERATIVE CENTRAL CORNEAL } \\
\text { THICKNESS IN UNEVENTFUL SICS }\end{array}$} \\
\hline $\begin{array}{l}\% \text { Of change in CCT } \\
\text { at } 3 \text { month }\end{array}$ & 3.48 \\
\hline CCT PRE-OP & 526 \\
\hline
\end{tabular}

The above table and graph shows pre-operative and post-operative central corneal thickness in uneventful SICS patients.

In the 180 patients who had uneventful SICS, the mean CCT pre-operatively was $526 \pm 37$ and the mean ECD at 3 months was $545 \pm 38$ indicating $3.48 \%$ change in CCT at 3 months post-operatively.

Table-5: Comparison of Endothelial cell density (cells $/ \mathrm{mm}^{2}$ ) and central corneal thickness (microns) in uneventful SICS patients at 3 months post operative period.

\begin{tabular}{|l|c|c|c|c|c|c|c|c|c|}
\hline Complication & $\begin{array}{c}\text { No } \\
\text { of } \\
\text { pts }\end{array}$ & $\begin{array}{c}\text { ECD } \\
\text { pre-op } \\
(\text { mean } \pm \text { SD })\end{array}$ & $\begin{array}{c}\text { CCT } \\
\text { pre-op } \\
(\text { mean } \pm \text { SD })\end{array}$ & $\begin{array}{c}\text { ECD } \\
\text { at 3 } \\
\text { months } \\
(\text { mean } \pm \text { SD })\end{array}$ & $\begin{array}{c}\text { CCT at 3 } \\
\text { months } \\
(\text { mean } \pm \text { SD })\end{array}$ & $\begin{array}{c}\text { \% Of Cell } \\
\text { loss at 3 } \\
\text { months } \\
\text { post op }\end{array}$ & $\begin{array}{c}\text { P } \\
\text { value }\end{array}$ & $\begin{array}{c}\text { \% Of change } \\
\text { in CCT at 3 } \\
\text { months }\end{array}$ & $\begin{array}{c}\text { P } \\
\text { value }\end{array}$ \\
\hline Uneventful & 180 & $2745 \pm 279$ & $526 \pm 37$ & $2485 \pm 369$ & $545 \pm 38$ & 9.5 & $<0.001$ & 3.48 & 0.13 \\
\hline
\end{tabular}

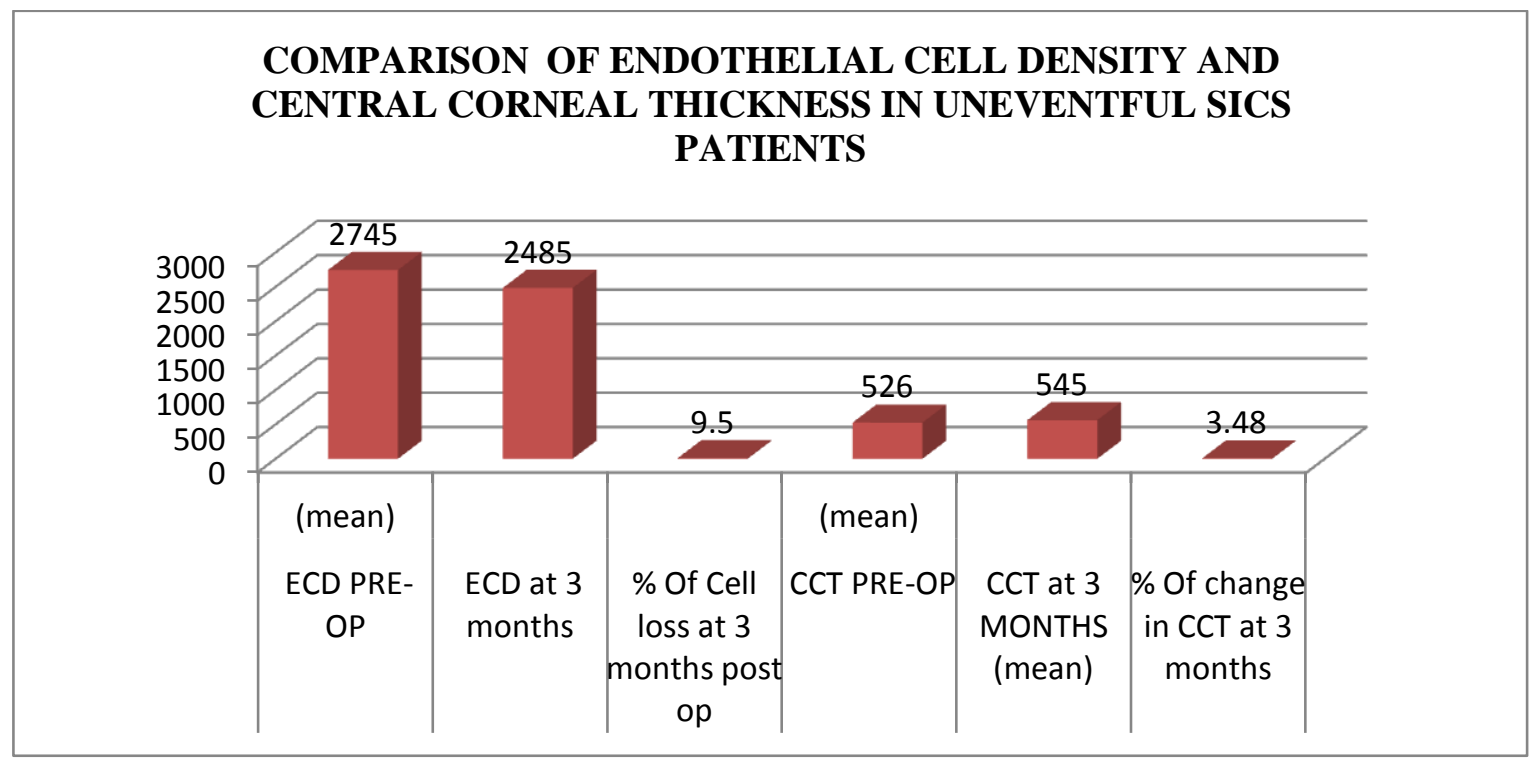

The above table and graph shows comparison of endothelial cell density and central corneal thickness pre-operatively and post-operatively at $3^{\text {rd }}$ month in uneventful SICS patients. 


\section{JMSCR Vol||07||Issue||07||Page 985-994||July}

In the 180 patients who had uneventful SICS, the mean ECD pre-operatively was $2745 \pm 279$ and the mean ECD at 3 months was $2485 \pm 369$ indicating $9.5 \%$ of cell loss at 3 months post-operatively and the mean CCT pre-operatively was $526 \pm 37$ and the mean ECD at 3 months was $545 \pm 38$ indicating $3.48 \%$ change in $\mathrm{CCT}$ at 3 months post-operatively.

Table-6: Pre-operative and Post-operative Endothelial cell density (cells $/ \mathrm{mm}^{2}$ ) in SICS patients in relation to surgical complications.

\begin{tabular}{|c|c|c|c|c|c|c|c|c|}
\hline Complications & $\begin{array}{c}\text { No of } \\
\text { pts }\end{array}$ & $\begin{array}{c}\text { Pre-op } \\
\text { ECD } \\
(\text { mean } \pm \text { SD })\end{array}$ & $\begin{array}{l}1^{\text {st }} \text { wk ECD } \\
(\text { mean } \pm \text { SD })\end{array}$ & $\begin{array}{c}2^{\text {nd }} \text { wk } \\
\text { ECD } \\
(\text { mean } \pm \text { SD })\end{array}$ & $\begin{array}{l}4^{\text {th }} \text { wk ECD } \\
(\text { mean } \pm \text { SD })\end{array}$ & $\begin{array}{c}\text { 3months } \\
\text { ECD } \\
\text { (mean } \pm \text { SD) }\end{array}$ & $\begin{array}{c}\% \text { Of } \\
\text { Cell loss } \\
\text { at } 3 \\
\text { month } \\
\text { postop } \\
\end{array}$ & $\begin{array}{c}P \\
\text { value }\end{array}$ \\
\hline Instrumental trauma & 11 & $3049 \pm 413$ & $2480 \pm 362$ & $2182 \pm 432$ & $2127 \pm 572$ & $2280 \pm 595$ & 25.2 & 0.001 \\
\hline iris prolapse & 14 & $2410 \pm 135$ & $1873 \pm 144$ & $1562 \pm 108$ & $1437 \pm 630$ & $1949 \pm 108$ & 19.1 & 0.001 \\
\hline Vitreous loss & 9 & $2925 \pm 387$ & $2528 \pm 546$ & $2370 \pm 460$ & $2348 \pm 562$ & $2588 \pm 380$ & 11.5 & 0.039 \\
\hline IOL Contact & 7 & $2799 \pm 195$ & $2329 \pm 331$ & $2348 \pm 442$ & $2315 \pm 388$ & $2431 \pm 325$ & 13.1 & 0.003 \\
\hline Posterior Capsular Rent & 1 & $2872 \pm 500$ & $2549 \pm 576$ & $2387 \pm 437$ & $2465 \pm 469$ & $2547 \pm 478$ & 11.3 & 0.210 \\
\hline Total & 42 & $2772 \pm 302$ & $2377 \pm 371$ & $2298 \pm 401$ & $2322 \pm 423$ & $2478 \pm 382$ & 10.6 & $<0.001$ \\
\hline
\end{tabular}

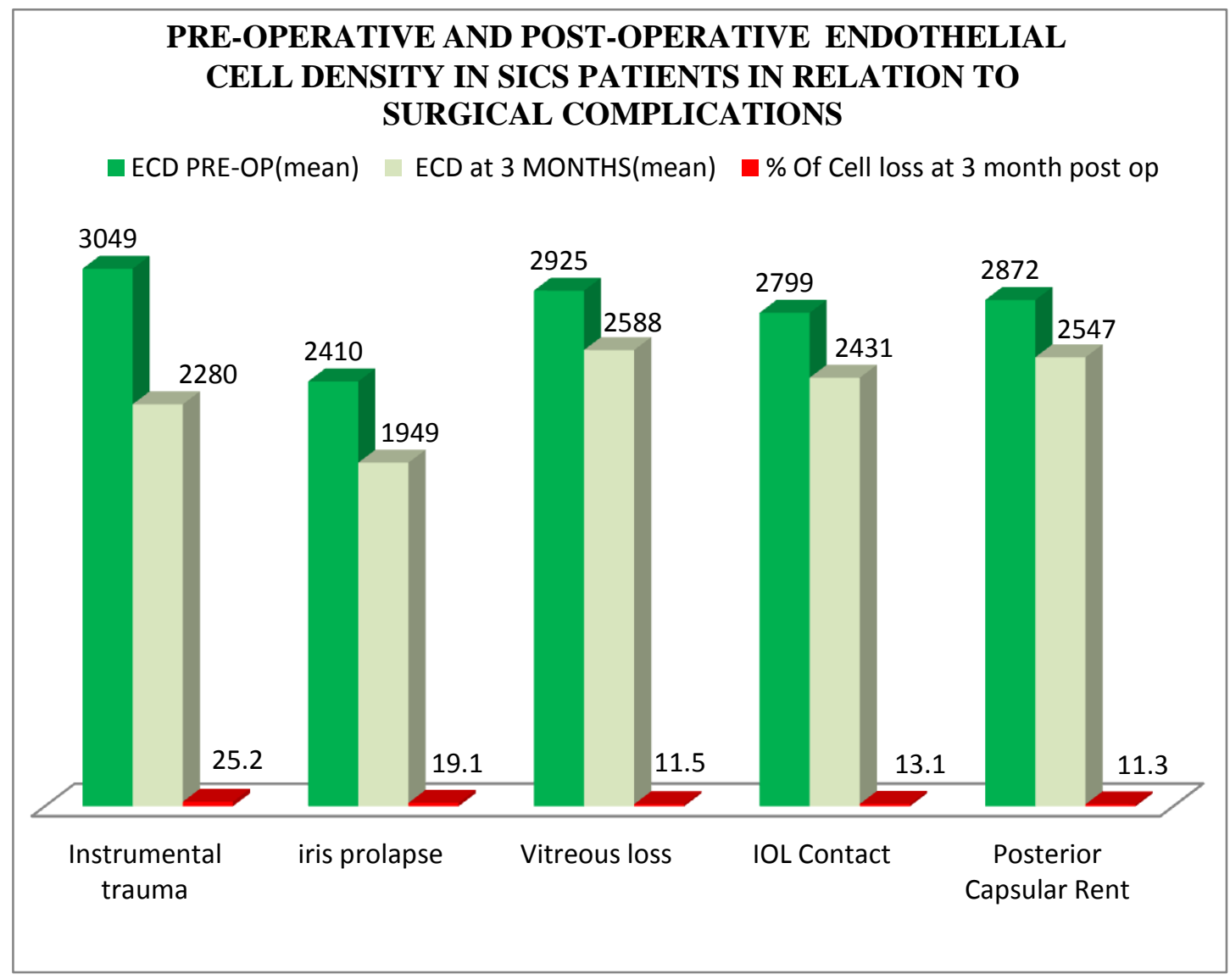

The above table and graph shows pre-operative and post-operative endothelial cell density in SICS patients in relation to surgical complications. In 11 patients with instrumental trauma, the mean ECD pre-op was $3049 \pm 413$ and the mean ECD at 3 months was $2280 \pm 595$ indicating $25.2 \%$ of cell loss at 3 months post-operatively.(p value 0.001$)$
In 14 patients with iris prolapse, the mean ECD preop was $2410 \pm 135$ and the mean ECD at 3 months was $1949 \pm 108$ indicating $19.1 \%$ of cell loss at 3 months post-operatively. ( $\mathrm{p}$ value 0.001 ) 


\section{JMSCR VoI||07||Issue ||07||Page 985-994||July}

In 9 patients with vitreous loss, the mean ECD preop was $2925 \pm 387$ and the mean ECD at 3 months was $2588 \pm 380$ indicating $11.5 \%$ of cell loss at 3 months post-operatively. ( $\mathrm{p}$ value0.039)

In 7 patients with IOL contact, the mean ECD preop was $2799 \pm 195$ and the mean ECD at 3 months was $2431 \pm 325$ indicating $13.1 \%$ of cell loss at 3 months post-operatively. ( $\mathrm{p}$ value 0.003 )
In 1 patient with posterior capsular rent, the mean ECD pre-op was $2872 \pm 500$ and the mean ECD at 3 months was $2547 \pm 478$ indicating $11.3 \%$ of cell loss at 3 months post-operatively. ( $p$ value 0.210 )

In total 42 patients with complications, the mean ECD pre-op was $2772 \pm 302$ and the mean ECD at 3 months was $2478 \pm 382$ indicating $10.6 \%$ of cell loss at 3 months post-operatively.

Table-7: Pre-operative and Post-operative Central corneal thickness (microns) in SICS patients in relation to surgical complications.

\begin{tabular}{|c|c|c|c|c|c|c|c|c|}
\hline Complication & $\begin{array}{l}\text { No } \\
\text { of } \\
\text { pts }\end{array}$ & $\begin{array}{l}\text { Preop } \\
\text { CCT } \\
(\text { mean } \pm \text { SD })\end{array}$ & $\begin{array}{l}1^{\text {st }} \text { wk CCT } \\
(\text { mean } \pm \text { SD })\end{array}$ & $\begin{array}{l}2^{\text {nd }} \mathbf{w k} \\
\text { CCT } \\
(\text { mean } \pm S D)\end{array}$ & $\begin{array}{l}4^{\text {th }} \text { wk CCT } \\
(\text { mean } \pm \text { SD })\end{array}$ & $\begin{array}{l}\text { CCT at } \\
\text { 3months } \\
\text { post-op } \\
(\text { mean } \pm \text { SD })\end{array}$ & $\begin{array}{l}\% \text { Of } \\
\text { change in } \\
\text { CCT at } 3 \\
\text { month }\end{array}$ & $\begin{array}{l}P \\
\text { value } \\
(Z \\
\text { test) }\end{array}$ \\
\hline $\begin{array}{l}\text { Instrumental } \\
\text { trauma }\end{array}$ & 11 & $520 \pm 42$ & $559 \pm 32$ & $563 \pm 22$ & $550 \pm 22$ & $546 \pm 29$ & 5.0 & 0.056 \\
\hline iris prolapse & 14 & $535 \pm 56$ & $590 \pm 31$ & $562 \pm 45$ & $551 \pm 28$ & $545 \pm 27$ & 2.0 & 0.059 \\
\hline Vitreous loss & 9 & $525 \pm 49$ & $550 \pm 46$ & $531 \pm 50$ & $513 \pm 51$ & $530 \pm 49$ & 0.9 & 0.082 \\
\hline IOL Contact & 7 & $541 \pm 44$ & $574 \pm 54$ & $538 \pm 49$ & $545 \pm 40$ & $531 \pm 36$ & 1.9 & 0.640 \\
\hline PCR & 1 & $525 \pm 35$ & $553 \pm 63$ & $527 \pm 18$ & $515 \pm 28$ & $530 \pm 27$ & 0.9 & 0.082 \\
\hline Total & 42 & $527 \pm 39$ & $565 \pm 42$ & $554 \pm 38$ & $545 \pm 37$ & $557 \pm 28$ & 5.8 & 0.124 \\
\hline
\end{tabular}

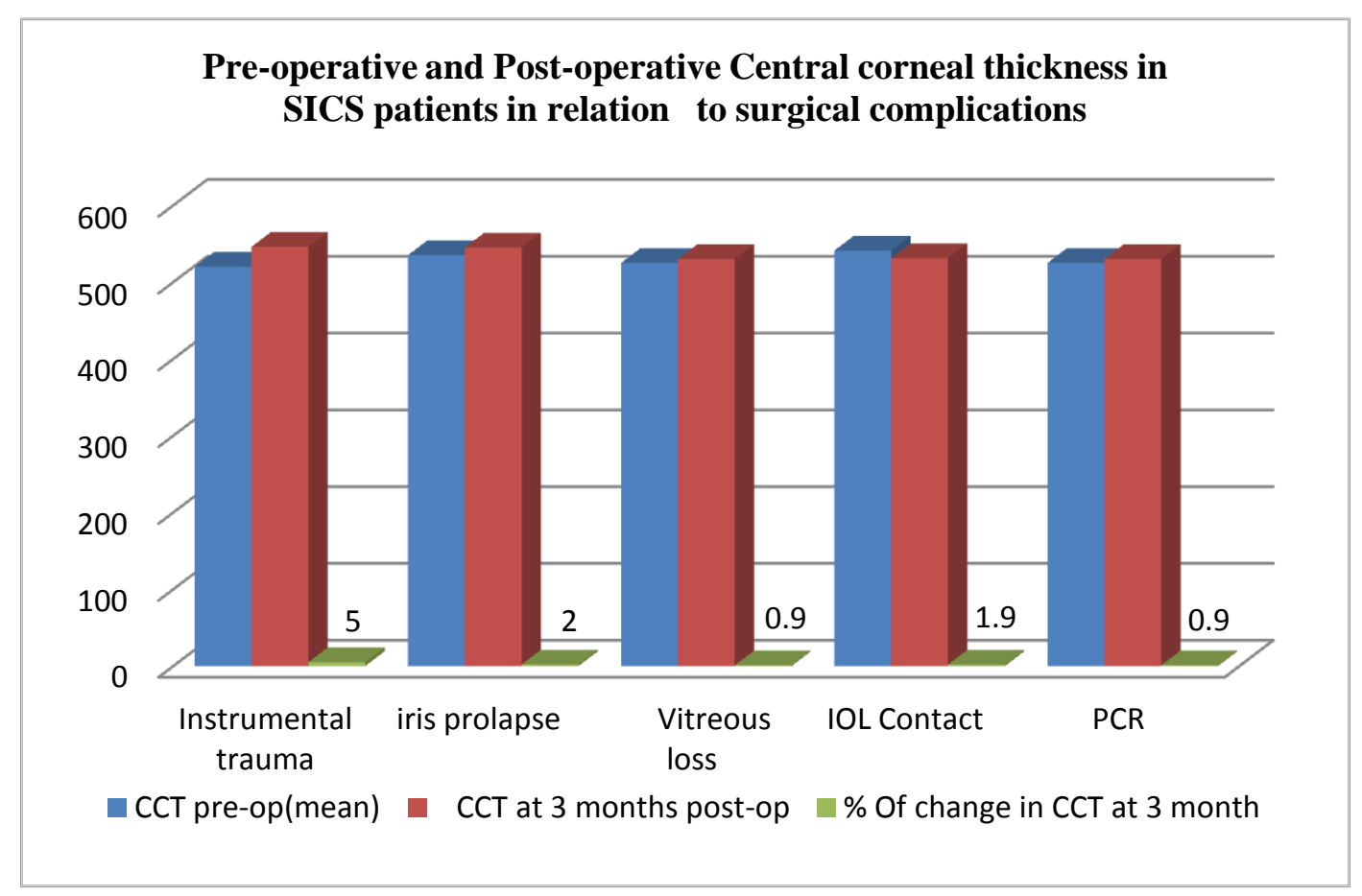

The above table and graph shows pre-operative and post-operative central corneal thickness in SICS patients in relation to surgical complications. In 11 patients with instrumental trauma, the mean CCT pre-operatively was $520 \pm 42$ and the mean CCT at 3 months post-operatively was $546 \pm 29$ indicating $5 \%$ change in CCT at 3 months post-operatively.(p value 0.056$)$
In 14 patients with iris prolapse, the mean CCT preoperatively was $535 \pm 56$ and the mean CCT at 3 months post-operatively was $545 \pm 27$ indicating $2 \%$ change in CCT at 3 months post-operatively. ( $p$ value 0.059 )

In 9 patients with vitreous loss, the mean CCT preoperatively was $525 \pm 49$ and the mean CCT at 3 months post-operatively was $530 \pm 49$ indicating $0.9 \%$ 


\section{JMSCR Vol||07||Issue ||07||Page 985-994||July}

change in CCT at 3 months post-operatively. ( $p$ value 0.082 )

In 7 patients with IOL contact, the mean CCT preoperatively was $541 \pm 44$ and the mean CCT at 3 months post-operatively was $531 \pm 36$ indicating $1.9 \%$ change in CCT at 3 months post-operatively. (p value 0.640 )

In 1 patient with posterior capsular rent, the mean CCT pre-operatively was $525 \pm 35$ and the mean
CCT at 3 months post-operatively was $530 \pm 27$ indicating $0.9 \%$ change in $\mathrm{CCT}$ at 3 months postoperatively. (p value 0.082 )

In total 42 patients with all surgical complications, the mean CCT pre-operatively was $527 \pm 39$ and the mean CCT at 3 months post-operatively was $557 \pm 28$ indicating $5.8 \%$ change in CCT at 3 months post-operatively. (p value 0.124 ).

Table-8: Comparison of Endothelial cell Density (cells $/ \mathrm{mm}^{2}$ ) and central corneal thickness (microns) in SICS patients in relation to surgical complications at 3 months post operative period.

\begin{tabular}{|c|c|c|c|c|c|c|c|c|c|}
\hline Complication & $\begin{array}{l}\text { No } \\
\text { Of } \\
\text { pts }\end{array}$ & $\begin{array}{c}\text { Pre-op } \\
\text { ECD } \\
(\text { mean } \pm \text { SD })\end{array}$ & $\begin{array}{c}\text { Pre-op } \\
\text { CCT } \\
(\text { mean } \pm \text { SD })\end{array}$ & $\begin{array}{c}\text { 3months } \\
\text { ECD } \\
(\text { mean } \pm \text { ECD })\end{array}$ & $\begin{array}{c}\text { 3months } \\
\text { CCT } \\
(\text { mean } \pm \text { SD })\end{array}$ & $\begin{array}{c}\% \text { Of } \\
\text { Cell Loss } \\
\text { At } 3 \\
\text { Month } \\
\text { Post Op }\end{array}$ & $\begin{array}{c}\text { ECD } \\
\mathbf{P} \\
\text { value }\end{array}$ & $\begin{array}{c}\% \text { Of } \\
\text { Change } \\
\text { In CCT } \\
\text { At } 3 \\
\text { Month }\end{array}$ & $\begin{array}{c}\mathbf{C C T} \\
\mathbf{p} \\
\text { value }\end{array}$ \\
\hline $\begin{array}{l}\text { Instrumental } \\
\text { Trauma }\end{array}$ & 11 & $3049 \pm 413$ & $520 \pm 42$ & $2280 \pm 595$ & $546 \pm 29$ & 25.2 & 0.001 & 5.0 & 0.056 \\
\hline Iris Prolapse & 14 & $2410 \pm 135$ & $535 \pm 56$ & $1949 \pm 108$ & $545 \pm 27$ & 19.1 & 0.001 & 2.0 & 0.059 \\
\hline Vitreous Loss & 9 & $2925 \pm 387$ & $525 \pm 49$ & $2588 \pm 380$ & $530 \pm 49$ & 11.5 & 0.039 & 0.9 & 0.082 \\
\hline IOL Contact & 7 & $2799 \pm 195$ & $541 \pm 44$ & $2431 \pm 325$ & $531 \pm 36$ & 13.1 & 0.003 & 1.9 & 0.640 \\
\hline PCR & 1 & $2872 \pm 500$ & $525 \pm 35$ & $2547 \pm 478$ & $530 \pm 27$ & 11.3 & 0.210 & 0.9 & 0.082 \\
\hline Total & 42 & $2772 \pm 302$ & $527 \pm 39$ & $2478 \pm 382$ & $557 \pm 28$ & 10.6 & $<0.001$ & 5.8 & 0.124 \\
\hline
\end{tabular}

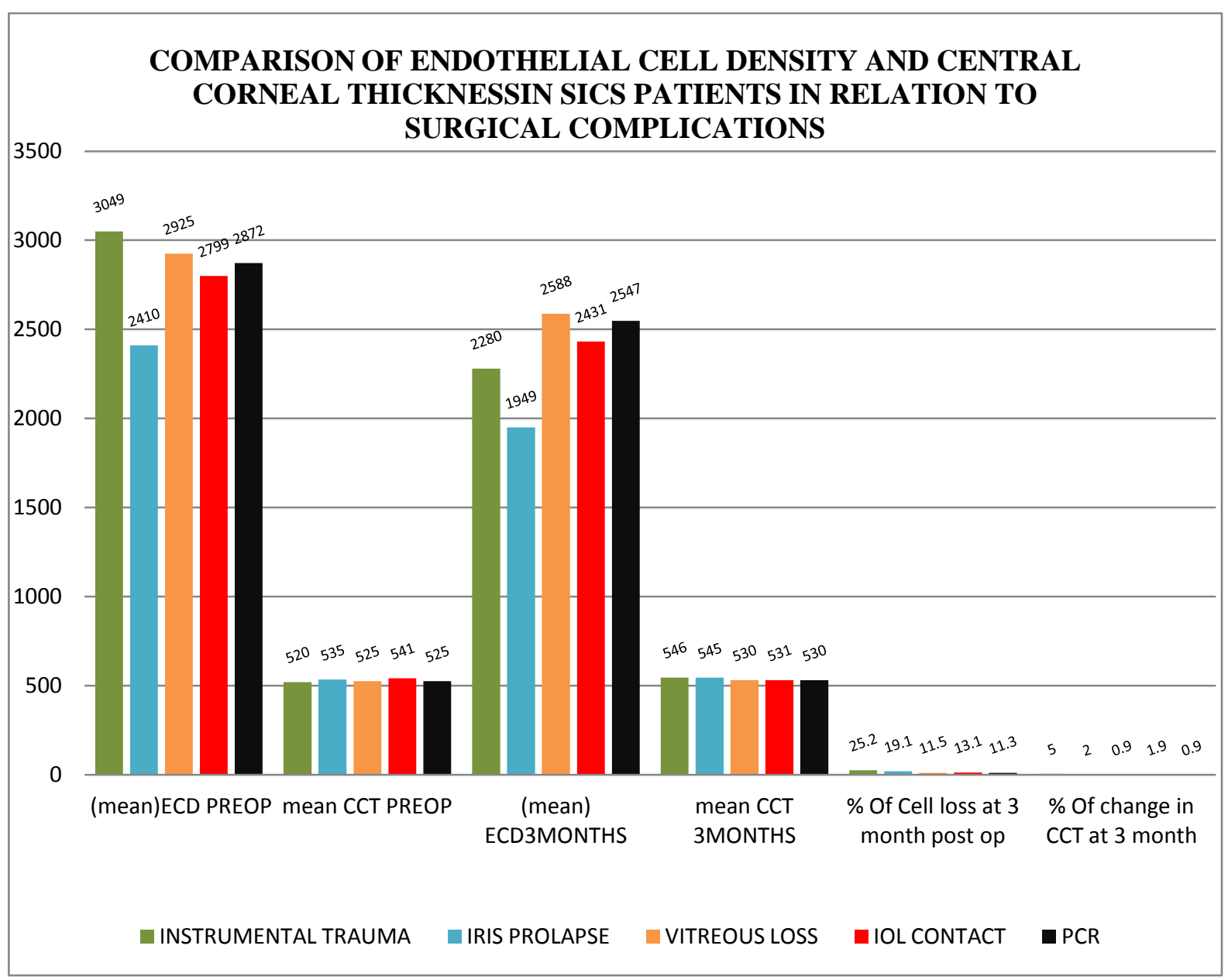


The above table and graph shows ccomparison of endothelial cell density and central corneal thickness in SICS patients in relation to surgical complications.

In 11 patients with instrumental trauma, the mean ECD pre-op was $3049 \pm 413$ and the mean ECD at 3 months was $2280 \pm 595$ indicating $25.2 \%$ of cell loss at 3 months post-operatively. Also, the mean CCT pre-operatively was $520 \pm 42$ and the mean CCT at 3 months post-operatively was $546 \pm 29$ indicating $5 \%$ change in CCT at 3 months post-operatively.

In 14 patients with iris prolapse, the mean ECD preop was $2410 \pm 135$ and the mean ECD at 3 months was $1949 \pm 108$ indicating $19.1 \%$ of cell loss at 3 months post-operatively. Also, the mean CCT preoperatively was $535 \pm 56$ and the mean CCT at 3 months post-operatively was $545 \pm 27$ indicating $2 \%$ change in CCT at 3 months post-operatively.

In 9 patients with vitreous loss, the mean ECD preop was $2925 \pm 387$ and the mean ECD at 3 months was $2588 \pm 380$ indicating $11.5 \%$ of cell loss at 3 months post-operatively. Also, the mean CCT preoperatively was $525 \pm 49$ and the mean CCT at 3 months post-operatively was $530 \pm 49$ indicating $0.9 \%$ change in CCT at 3 months post-operatively.

In 7 patients with IOL contact, the mean ECD preop was $2799 \pm 195$ and the mean ECD at 3 months was $2431 \pm 325$ indicating $13.1 \%$ of cell loss at 3 months post-operatively. Also, the mean CCT preoperatively was $541 \pm 44$ and the mean CCT at 3 months post-operatively was $531 \pm 36$ indicating $1.9 \%$ change in CCT at 3 months post-operatively.

In 1 patient with posterior capsular rent, the mean ECD pre-op was $2872 \pm 500$ and the mean ECD at 3 months was $2547 \pm 478$ indicating $11.3 \%$ of cell loss at 3 months post-operatively. Also, the mean CCT pre-operatively was $525 \pm 35$ and the mean CCT at 3 months post-operatively was $530 \pm 27$ indicating $0.9 \%$ change in CCT at 3 months post-operatively.

In the total 42 patients with complications, the mean ECD pre-op was $2772 \pm 302$ and the mean ECD at 3 months was $2478 \pm 382$ indicating $10.6 \%$ of cell loss at 3 months post-operatively. Also, the mean CCT pre-operatively was $527 \pm 39$ and the mean CCT at 3 months post-operatively was $557 \pm 28$ indicating $5.8 \%$ change in CCT at 3 months post-operatively.

\section{Conclusion}

The present study comprised of 222 cases who underwent small incision cataract surgery between 2018 November-2019 October in Department Of Ophthalmology in Karwar Institute of Medical Sciences and Hospital Karwar. The results of surgery were studied prospectively over a 3 month period with follow ups at 1 week, 2 weeks, 1 month and 3 months. In this present study attempt was made to access the relation between Central Corneal Endothelial Cell Density and Central Corneal Thickness after small incision cataract surgery and effect of various factors like intra operative complications.

\section{Age \& Gender Distribution}

The study was conducted on 222 patients out of which $50 \%$ were males and rest females. Out of 222 patients, $81(36.5 \%)$ patients were in the age group of 50-59 years of whom $47(42.3 \%)$ patients were females and $34(30.6 \%)$ were males. 94 (42.3\%) patients were in the age group of 60-69 years of whom $40(36.0 \%)$ patients were females and 54 $(48.6 \%)$ were males. $40(18.0 \%)$ patients were in the age group of 70-79 years of whom 19 (17.1\%) patients were females and $21(18.9 \%)$ were males.7(3.2\%) patients were in the age group of $>80$ years of whom $5(4.5 \%)$ patients were females and $2(1.8 \%)$ were males.

\section{Effect of Surgical Complications on Endothelial Cell Density and Central Corneal Thickness in SICS Patients}

In the present study, total 222 patients underwent SICS with PCIOL which were divided into 3 groups:

G1 -Irrigating vectis technique-73 patients

G2 -Sandwich technique-75 patients

G3 -Visco expression technique-74 patients

73 patients were operated with irrigating vectis technique, in that total complications were 24 (57.14\%), including instrumental trauma $6(14.28 \%)$, iris prolapse 8 (19.04\%), vitreous loss $6(14.28 \%)$, IOL contact $3(7.14 \%)$ and PCR $1(2.38 \%)$. The \% 
of endothelial cell loss and increase in CCT with this technique was $16.07 \%$ and $11.9 \%$.

Wright et al (1994) ${ }^{12}$ performed SICS in 90 eyes using irrigating vectis technique. They reported $14.4 \%$ endothelial cell loss and $10.8 \%$ in increase in central thickness at 1 month and $10.1 \%$ endothelial cell loss and $7.2 \%$ increase in central corneal thickness at 4 month. Complications were posterior capsule rupture $8.1 \%$, instrumental trauma $7.2 \%$, vitreous loss $1.8 \%$ and others $3.6 \%$.

Thakur et al (2011) ${ }^{13}$ performed SICS in 150 eyes using irrigating technique. At the end of 3 months complications reported were surgical trauma $12.6 \%$, iris prolapsed $10.8 \%$, posterior capsular rupture $5.4 \%$ and vitreous loss $3.6 \%$ and there was $16 \%$ endothelial cell loss.

In our study, 75 patients were operated with sandwich technique, in that total complications were $9(21.42 \%)$, which includes instrumental trauma 3 $(7.14 \%)$, iris prolapse $2(4.76 \%)$, vitreous loss 2 (4.76\%), IOL contact $2(4.76 \%)$ and no PCR. The \% of endothelial cell loss and increase in CCT with this technique was $10.46 \%$ and $2.1 \%$.

Smith et al (1992) ${ }^{14}$ performed SICS in 60 eyes using sandwich technique. After 3 months there was $10.2 \%$ endothelial cell loss and $6 \%$ increase in central corneal thickness. Complications were instrumental trauma $6.3 \%$, iris prolapsed $4.5 \%$, posterior capsule rupture $(2 \%)$ and vitreous loss $1.8 \%$.

Jacobs PM et al (1994) ${ }^{15}$ performed SICS in 90 eyes using sandwich technique. They reported $12.6 \%$ endothelial cell loss and $8.1 \%$ in increase in central thickness at 1 month and $8.1 \%$ endothelial cell loss and $5.4 \%$ increase in central corneal thickness at 4 month. Complications were posterior capsule rupture $3 \%$, instrumental trauma $7 \%$, vitreous loss $1.8 \%$ and others $2 \%$.

In our study, 74 patients were operated with visco expression technique, in that total complications were $9(21.42 \%)$, which includes instrumental trauma $2(4.76 \%)$, iris prolapse $4(9.52 \%)$, vitreous loss $1(2.38 \%)$, IOL contact $2(4.76 \%)$ and no single PCR observed. With visco expression technique there was $5.26 \%$ endothelial cell loss and $1.8 \%$ increase in CCT.

Rao GN and Stevens et al (1994) ${ }^{16}$ performed SICS in 90 eyes using visco expression technique. They reported $12.6 \%$ endothelial cell loss and $8.1 \%$ in increase in central thickness at 1 month and $8.1 \%$ endothelial cell loss and $5.4 \%$ increase in central corneal thickness at 4 month. Complications were posterior capsule rupture $3 \%$, instrumental trauma $7 \%$, vitreous loss $1.8 \%$ and others $2 \%$.

Sunil Ganekal et al (2014) ${ }^{17}$ performed SICS in 100 eyes using visco expression technique. They reported $13.9 \%$ endothelial cell loss .Complications were posterior capsule rupture $3 \%$, instrumental trauma $7 \%$, vitreous loss $1.8 \%$ and others $2 \%$.

\section{Uneventful Surgery}

In this present study, out of 222 patients, 180 patients had uneventful Small Incision Cataract Surgery, the mean ECD pre-operatively was $2745 \pm 279$ and the mean ECD at 3 months was $2485 \pm 369$ indicating $9.5 \%$ of cell loss at 3 months post-operatively ( $\mathrm{p}$ value $<0.001$ ) and the mean CCT pre-operatively was $526 \pm 37$ and the mean ECD at 3 months was $545 \pm 38$ indicating $3.48 \%$ change in CCT at 3 months post-operatively $9 \mathrm{p}$ value 0.13).

Our study correlate with studies of uneventful cataract extraction reported by Kraff et al (1980) ${ }^{18}$ showed a mean endothelial cell loss of $12.3 \%$.

Bourne et al (1988) $)^{19}$ reported an average of $10 \%$ reduction in endothelial cell count by one year after uneventful phacoemulsification and ECCE.

\section{References}

1. A K Khurana, Indu Khurana Anatomy and Physiology of Eye $2^{\text {nd }}$ edition, 2006

2. Rupert R. A. Bourne, BSc, FRC Ophth, 1, 2 Darwin C. Minassian, FRCOphth, MSc (Epidem). Effect of cataract surgery on corneal endothelium: modern phacoemulsification compared with extra capsular cataract surgery. Ophthalmology 2004;111:679-685 (C) 2004 by the American Academy of Ophthalmology 
3. Dr. Alyaa Abood Kareem. M.B.Ch.B, F.I.C.M.S ophth. C.A.B ophth. Medical College-Kufa University Maan Abdul Ameer Kitab Alged. M.B.Ch.B. Evaluation of Corneal Endothelial Cells Hysteresis after Phacoemulsification Kufa Med. Journal 2012.VOL.15.No.1. 362

4. Mohamed AE Soliman Mhdy, Mohamed Zeid, Mohamed Abdel BadeiMohammed, Amr Hafez and Jagdish Bhatia. Relationship between endothelial cell loss and micro axial phacoemulsification parameters in no complicated cataract surgry. PMCID; PMC3334211Clin Ophthal.2012;6503-510

5. Shultz RO,Matsuda M,Yee RW, Corneal endothelium changes in type-I and type-II Diabetes mellitus American journal of ophthal mology 1984;98;401-410.

6. Hayashi K, Yoshida M, Manabe S, Hiarata A. Cataract surgery in eyes with low endothelial cell density $\mathrm{J}$ cataract refract surg.2011;37(8) 1419-1425

7. Mohammad Nasser Hashemian, Sasan Moghimi, Masood Aghsaie, Fard, Mohammad Reza Fallah and Mohammad Reza Mansouri Corneal endothelial cell density and morphology in normal Iranian eyes. BMC Ophthalmology 2006,6;9 doi;10.1186/1471-2415-6-9.

8. Storr-Paulsen A, Norregaard JC, Ahmed S, Storr-Paulsen T, Pedersen TH.Endothelial cell damage after cataract surgery: divideand-conquer versus phaco-chop technique. Department of Ophthalmology, Frederiksberg University Hospital, Frederiksberg, Denmark..Endothelial cell damage with phacoemulsification techniques. [J Cataract Refract Surg. 2009

9. Gogate $\mathrm{P}$, Ambardekar P, Kulkarni S, Deshpande R, Joshi S, Deshpande M. Comparison of endothelial cell loss after cataract surgery: phacoemulsification versus manual small-incision cataract surgery: sixweek results of a randomized control trial. H.V. Desai Eye Hospital, 73/2 Tarawade
Wasti, Mohammadwadi, Hadapsar, Pune411028, India. J Cataract Refract Surg. 2010 Feb;36(2):247-53.

doi: 10.1016/j.jcrs.2009.09.023.

10. Dafna Goldenberg, Zohar Habot-Wilner, Yoseph Glovinsky, Irina S. Barequet Endothelial cells and central corneal thickness after modified sutureless manual small-incision cataract surgery European Journal Oph

11. Albert DM, Henkind P. Men of Vision. Lives of Notable Figures in Ophthalmology. WB Saunders, 1993

12. Kelman CD "Phacoemulsification and aspiration: a new technique of cataract removal. A preliminary report" Am J Ophthalmol1967;64:23-35

13. James A Davison, Leo T Chylack. Clinical application of the lens opacities classification system III in the performance of phacoemulsification. Journal of Cataract and Ref Surgery; 2003 Jan; 29 (1): 138-145

14. Smith, Gurung R, Hennig A. Small incision cataract surgery: Tips for avoiding surgical complications. Community Eye Health 2008; 21: 4-5

15. Jacobs PM Bellucci R, Morselli S et al. Nucleus viscoexpression compared with other techniques of nucleus removal in extra capsular cataract extraction with capsulorrhexis. Ophthalmic Surgery 1994; 25(7): 432-7

16. Rao GN Ravi Thomas et al. Methods of nucleus extraction; ECCE - Surgical techniques.IJO 1993; 4(4): 202-206 127

17. Sunil Ganekal. J Akura et al. "Manual Sutureless Cataract Surgery using Claw Vectis" Journal of cataract and Refractive surgery; 2000(26): 491-496. 